\title{
FINANCIAL LITERACY AS A FACTOR OF CASHLESS PAYMENTS DEVELOPMENT. RESULTS OF SURVEY
}

\author{
BEATA ŚWIECKA \\ University of Szczecin, Faculty of Management and Economics of Services, POLAND \\ e-mail: beata.swiecka@wzieu.pl
}

\begin{abstract}
\begin{tabular}{l|l} 
RECEIVED & 18 January 2018
\end{tabular}
\begin{tabular}{l|l} 
ACCEPTED & 2 September 2018
\end{tabular}

JEL

CLASSIFICATION

D10, D14, D18, G20, I22

KEYWORDS cashless payment, financial literacy, payments cards, mobile payment

ABSTRACT The aim of the article is to analyze financial literacy in cashless payment. In the articles propose a hypothesis: financial literacy is one of the factor influence of cashless payments. This hypothesis is complemented by the statement that people with a higher financial knowledge and skills more often use cashless payments. In order to achieve the goal, it will describe the main factors of cashless payments. The article will also show the results of own research, which was carried out of the Foundation for the Development of Cashless Transactions using the research institute IPSOS. The own research shows the importance of financial literacy in the development of cashless transactions.
\end{abstract}

\section{Introduction}

Topics related to non-cash payments are a very important and multifaceted area of research investigation in sciences of finance. Their strength is in the diversity and complexity of the problem. Due to the pragmatic nature of cashless payments, there is a need to enrich their theoretical achievements. It is important to an acquire new knowledge of a descriptive and normative character because such knowledge allows explaining the phenomena 
studied and to formulate recommendations for business practice in terms of the theory of cashless payments. In theory and practice, it is important to recognize and understand how financial literacy affects the development of cashless payments. The aim of the article is to analyze financial literacy in cashless payment. In the articles propose a hypothesis: financial literacy is one of the factor influence of cashless payments. This hypothesis is complemented by the statement that people with a higher of financial knowledge and skills more often use cashless payments. In order to achieve the goal, it will describe the main factors of cashless payments. The article will also show the results of own research, which was carried out of the Foundation for the Development of Cashless Transactions using the research institute IPSOS. The own research shows the importance of financial literacy in the development of non-cash transactions. The survey was carried out using the CAPI (Computer-Assisted Personal Interview) method, from February 9 to March 1, 2018. In survey was using a questionnaire. The survey was conducted on the Polish nation at age 15 and more. A total number of interviews was 1,100. To ensure the representativeness of the collected data, edge weighing was carried out to the structure of the Polish population aged 15 and more using rim weighting.

\section{Factors influencing the development of cashless payments. Literature review}

According Programme for non-cash payments development in Poland for the years 2014-2020 (2015), that "in 2020, Poland is a country in which:

- society, entrepreneurs, and public institutions use non-cash payment instruments knowingly and commonly,

- favourable conditions are ensured for the development of non-cash payments through the use of a safe, innovative, competitive and effective payment system in Poland,

- there are no barriers to access and use of payment services associated with non-cash payments".

If Poland in 2020 has to be as mentioned above is necessary to develop cashless payments, which is dependent on many factors. Among the selected factors are the development of cooperation between banks, cashless network operators, banking, consumer bank association, the central bank, and the other (Figure 1, factor 1). Cooperation between institutions contributes to multidirectional activity and faster development of cashless payments. An example of such cooperation is a joint initiative of banks, Visa and Mastercard organizations, which enabled small and medium enterprises to use POS terminals for free (O PLN). This initiative "Cashless Poland" is supported by the Ministry of Development and the Association of Polish Banks. The aim is to equalize the availability of non-cash payments with cash by doubling the number of terminals in the next three years, which according to the National Bank of Poland in the first quarter of 2018 were over 600 thousand (NBP, 2018, p. 1). A large role in cooperation in cashless payment is played institutions introducing regulations (Figure 1, factor 2). For example limitations in the field of cash settlements between companies. From January 1, 2017, the limit of cash payments in transactions between entrepreneurs dropped from 15 thousand. euros up to 15 thousand PLN (Polish Zloty), it is (around EUR 3 500). The limit applies to the transaction amount, not a single payment. This means that if the payment is an installment, the payment method should depend on the total amount of the transaction. The above limit applies to both domestic and foreign transactions. Another factor is technological development (Figure 1, factor 3), whose dynamic development allows introducing new solutions for cashless, including contactless payments or mobile payments. Technological innovations alone are not enough, necessary is infrastructure (Figure 1, factor 4), including an ATMs network or POS terminals. According to a data of Polish Central bank, at the end of 2017 in Poland, were 23,230 ATMs. Between March and December 2017 in Poland, the number of ATMs has decreased by 
521 units. In the fourth quarter of 2017, there were 167.4 million cash withdrawal transactions in ATMs across the country. In comparison to the previous quarter (III Q 2017), there was a decrease in the number of withdrawals by 6.8 million, which was decreased by $3.9 \%$. The value of withdrawals at ATMs in the fourth quarter 2017 dropped to 83.5 billion PLN. This is 1.8 billion less than was paid in the third quarter of 2017 (NBP, 2018, p. 1). Reducing the number of cash transactions (in ATM) which proves the development of a non-cash society. A factor conducive to the development of cashless payments is time (Figure 1, factor 5 ). If longer the instrument is on the market, the more consumers use it. The time of functioning on the market of non-cash payment instruments is related to factor 6 consumer readiness (Figure 1, factor 6 ). Consumer readiness is consumers openness to cashless payments, new ideas in this area. In the initial development of non-cash payments market (1991 business cards, 1993 classic cards) was quite difficult. The Poles were very attached to cash, however, over time, openness to cashless payments was increasing. A big ally was time as well as knowledge (financial literacy) about new solutions. Last not but the is financial literacy, which is understood as effective and understandable. across the range of financial contexts, and to participate in the economic life (PISA, 2017, p. 49).

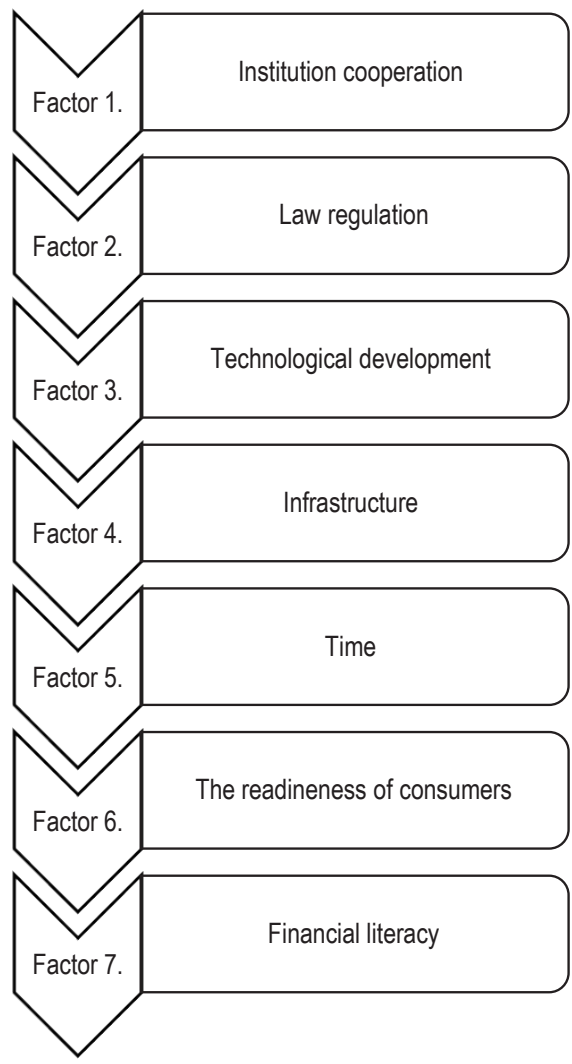

Figure 1. Main factors influencing the cashless payments

Source: own research. 


\section{Financial literacy conceptualisation. Litepature review}

Financial literacy is currently the subject of numerous professional and scientific discussions. Financial literacy can be defined as the "process by which financial consumers/investors improve their understanding of financial products and concepts and, through information, instruction and/or objective advice, develop the skills and confidence to become more aware of financial risks and opportunities, to make informed choices, to know where to go for help, and to take other effective actions to improve their financial well-being" (Becchetti, Caiazza, Coviello, 2013, pp. 817-836). Financial literacy not only implies a certain level of financial knowledge, but also an ability to apply the knowledge in action (Xiao O'Neill, 2016, pp. 712-721). According to Romiti and Rossi (2014, pp. 1-37), higher financial knowledge helps individuals to monitor an optimal consumption and balanced portfolio of household with relation to finances. Financially illiterates cannot fully participate in today's economy as such (Gavurova, Huculova, Kubak, Cepel, 2017, pp. 206-219). The research Uzonwanne and Ezenekwe (2017, p. 123139) show the impact of financial literacy on the cashless policy system in Nigerians life, using Lagos State as a case study. Results of questionnaire methods show that financial illiteracy has a negative impact on the utilization of the cashless system in Nigeria. Financial literacy is an important factor in personal finance management and also in cashless payment. A problem is also, that there is a sharp disconnect between how much people think they know and what they actually know (Lusardi, 2010, p. 20).

\section{Methods of own survey}

The primary (own) survey was carried out using the CAPI method from February 9 to March 1,2018 . Contents of the questionnaire: closed questions with an answer list and knowledge test in the field of payments. The survey was conducted on a nationwide sample of the population of Poland aged 15 and more. A total of 1,100 interviews were conducted. To ensure the representativeness of the collected data, edge weighing was carried out to the structure of the Polish population aged 15 and more using the interactive technique (rim weighting). Weighing will be performed in accordance with the structure of sex, age, and education. The scope of the primary study covered four issues:

- currently used payment methods,

- stimuli of the increase in non-cash turnover,

- payment methods that are an alternative to the cash payment,

- financial knowledge and financial skills in the field of payments (financial literacy).

For the purposes of the article, only one area of research is presented - financial literacy. The research was done under the scientific supervision of prof. J. Harasim and prof. Beaty Świecka. The research was made for the Foundation for the Development of Cashless Transactions using the research company IPSOS. Full results of the research were presented at the International Congress of Cashless Payments, which is held every year in March in Warsaw. A total number of interviews were 1,100 (15-60+ years old). In the survey, $52 \%$ were women's. People who use mostly cashless payments are people $25-39$ years old (43\%) and $31 \%$ (40-59 years old), and $60+$ years old $(9 \%)$ and $15-24$ years (17\%). Cashless payments are usually paid by people with higher education (36\%), who have enough money for life but live economically $(53 \%)$. 


\section{Results of own survey}

The results of primary (own) research show that: the group using card or phones paying for products or services is slightly smaller than the group of consumers who pay mostly or only by cash. People who prefer cashless payments more often belong to younger age groups and more often live in larger cities, have a higher education level and higher material status. Consumers who prefer cashless payments are mainly driven by practical considerations (the speed of payment and the desire to avoid the hassle of using cash for example: remembering to have cash, no "small coins" for parking, waiting for the rest, etc.). The majority of consumers thinks that in every place should be able to pay cashless. Respondents have a low opinion of their knowledge about cashless payments. Only $1 \%$ asses that have the very good knowledge, $30 \%$ think that have a good knowledge, $26 \%$ poor, and $4 \%$ hard to say and $9 \%$ do not have knowledge about financial matters at all.

Consumers have a higher level of knowledge about the cashless payment of the longest functioning on the market, eg debit and credit cards, and much less on cashless payment shorter on the market, eg virtual or relatively recently introduced forms of payment such as PayU, PayPal or BLIK. This test result confirms the importance of the time factor and also shows the relationship between time and financial literacy. The longer occurrence of a cashless product is closely related to financial literacy being at a higher level (Figure 2).

\begin{tabular}{|c|c|c|c|}
\hline Payment card with contactless function & \multicolumn{2}{|r|}{$69 \%$} & $25 \%$ \\
\hline e-Transfer & \multicolumn{2}{|r|}{$64 \%$} & $26 \%$ \\
\hline Fast transfer (PayU etc.) & \multicolumn{2}{|c|}{$38 \%$} & $33 \%$ \\
\hline Contactless payment via mobile phone & $17 \%$ & \multicolumn{2}{|c|}{$62 \%$} \\
\hline Payment by phone (remote, via the application) & $13 \%$ & \multicolumn{2}{|c|}{$60 \%$} \\
\hline
\end{tabular}

Figure 2. Knowledge and use of innovative forms of payment

Source: own survey.

Most consumers can use an ATM and payment card, more than half can buy and pay online, but only less than $40 \%$ would be able to pay by phone for shopping. Just like with financial knowledge, so it is also with financial skills. Most consumers have elementary financial skills, i.e. they can use an ATM and a payment card. Smaller financial skills consumers have to use recently introduced forms of payment, such as mobile payments, or payments using BLIK, or online payments. Financial skills are strictly correlated with the duration of the operation on the cashless product market and financial literacy. The longer the cashless product is on the market, the financial skills are higher. The vast majority of consumers would be able to behave properly in the case of a lost payment card or a request to provide access data to a bank account (Figure 3). 
Do you have skills, how to.....?

\begin{tabular}{|c|c|c|c|}
\hline Withdraw cash from an ATM & \multicolumn{2}{|c|}{$88 \%$} & $12 \%$ \\
\hline Pay with a payment cards (eg Visa, MasterCard) & \multicolumn{2}{|c|}{$86 \%$} & $14 \%$ \\
\hline Book a hotel online & $58 \%$ & \multicolumn{2}{|l|}{$42 \%$} \\
\hline Make bank account via internet & $57 \%$ & \multicolumn{2}{|l|}{$43 \%$} \\
\hline Pay by card on the Internet & $56 \%$ & \multicolumn{2}{|l|}{$44 \%$} \\
\hline Pay by phone on the Internet & $39 \%$ & $61 \%$ & \\
\hline
\end{tabular}

Figure 3. Skills to pay in different situations

Source: own survey.

\section{Conclusions}

Financial literacy as a set of financial knowledge and financial skills is necessary for everyone to who secure themselves in finance management, and who would like to be active in financial market. High level of financial literacy is the best way to prevent over-indebtedness, use innovation financial products. The results from own survey are:

1. Every fourth consumer acknowledges that his knowledge and skills in finance are weak.

2. Most consumers have elementary financial skills, i.e. they can use an ATM and a payment card. The percentage of consumers who can buy and pay for online shopping is much smaller, and almost $40 \%$ of respondents admitted that they could pay by phone for shopping.

3. The longer occurrence of a cashless payment product are closely related to financial literacy being at a higher level.

4. Consumers have the most knowledge about the most popular payment cards: debit, credit and contactless, but less about prepaid, virtual cards. The innovative forms of payment are also relatively less known (PayU, PayPal or BLIK).

5. People who prefer cashless payments have higher level of education and a higher material status.

6. People who have wider knowledge often use a cashless payment.

7. Financial skills are strictly correlated with the duration of the operation on the cashless product market and financial literacy. The longer the cashless product is on the market, the financial skills are higher. The vast majority of consumers would be able to behave properly in the case of a lost payment card or a request to provide access data to a bank account.

\section{References}

Alsemgeest, L. (2015). Arguments for and against financial literacy education: Where to go from here? International Journal of Consumer Studies, 39 (2),155-161.

Becchetti, L., Caiazza, S., Coviello, D. (2013). Financial education and investment attitudes in high school: evidence from a randomized experiment. Applied Financial Economics, 23, 817-836. 
Gavurova, B., Huculova, E., Kubak, M., Cepel, M. (2017). The state of student' financial literacy in selected Slovak universities and its relationship with active pension savings. Interdisciplinary Approach to Economics and Sociology, 10 (3), 206-219.

Harasim, J., Świecka, B. (2018). Raport z badań - Rola bodźców w zmianach preferencji płatniczych Polaków. Warszawa: Fundacja Rozwoju Obrotu Bezgotówkowego, IPSOS.

Lusardi, A. (2010). Americans' financial capability. Report prepared for the Financial Crisis Inquiry Commission. NBER Working Paper No. 17103. Dartmouth College:The National Bureau of Economic Research.

NBP (2018). NBP: liczba bankomatów systematycznie maleje. Polska Agencja Prasowa 3.05.2018.

PISA (2017). PISA 2015 Results. Students' financial literacy. Vol. IV. Paris: OECD.

Programme for non-cash payments development in Poland for the years 2014-2020 (2015). Coalition for Non-Cash Payments and Micropayments. Warszawa.

Romiti, A., Rossi, M. (2014). Wealth decumulation, portfolio composition and financial literacy among European elderly. Working Paper No. 375, Carlo Alberto Notebooks, Collegio Carlo Alberto, Universita Degli Studi Di Torno, December, 37.

Uzonwanne, M., Ezenekwe, U. (2017). Financial illiteracy and cashless system in Nigeria. Journal of Economics and Sustainable Development, 8 (9), 123-139.

Xiao, J., O'Neill, B. (2016). Consumer financial education and financial capability. International Journal of Consumer Studies, 40 (6), 712-721.

Cite this article aS: Świecka, B. (2018). Financial literacy as a factor of cashless payments development. Results of survey. European Journal of Service Management, 3 (27/2), 467-473. DOI: 10.18276/ejsm.2018.27/2-57. 